\title{
What, Then, is ‘Global' about Global Governance?
}

\author{
Esref Aksu \\ Independent Scholar, Melbourne, vIC 3082, Australia \\ esrefaksu@hotmail.com
}

\begin{abstract}
This article explores whether the notion of globality is as integral to the various conceptualisations of "global governance" in the pertinent literature as one would justifiably assume. The conceptual analysis here concentrates on well-established clusters of meaning attached to global governance. The main observation is that the nature of globality remains conceptually underdeveloped in the self-conscious global governance literature. The main suggestion against this backdrop is that conceptual clarity is both necessary and possible. Closer reflection on the use of "global" as a linguistic qualifier might prove a useful starting point when seeking such clarity.
\end{abstract}

\section{Keywords}

Global - Governance - Conceptual analysis

This article explores the notion of "globality" or "the global". ${ }^{1}$ I ask here simply: Is the notion of globality as integral to the various conceptualisations of "global governance" in the pertinent literature as one would justifiably

* I owe a debt of gratitude to the Center for Global Cooperation Research / Käte Hamburger Kolleg (Duisburg) for their generous fellowship which enabled me to conduct the research for this article. An earlier draft of the article was presented at the Center on 21 May 2013. I also would like to thank each and every permanent and visiting member of the Center for their continuous intellectual support.

1 Some texts use "globality", while others prefer "the global". Two representatives are, respectively, Jens Bartelson, "The social construction of globality", International Political Sociology, 4 (2010), pp. 219-235 and Robert Latham, "Politics in a floating world: Toward a critique of global governance", in Martin Hewson and Timothy J. Sinclair (eds), Approaches to Global Governance Theory, (Albany, NY: sunY Press, 1999). I will use these terms synonymously—henceforth 
assume? At least two other authors have already identified and addressed this conceptual problem. Jim Whitman and Matthew Hoffmann used an almost identical wording in 2005 to express their uneasiness with the concept. I have borrowed their formulation for the title of this article: "What, then, is 'global' about global governance?"2

This question might at first create the impression that I intend to look at the empirical world of events, occurrences, behaviour (empirically detectable thoughts and speech acts included); nominate where we can detect globality; and suggest certain criteria / indicators for specified phenomena to qualify as global. However, here I am not interested in what global governance is (empirically). Nor am I interested in what it should be (normatively). I will not try to describe, explain, judge, or advocate any particular notion of global governance as informed by empirical phenomena, i.e. in relation to the several practices which are generally deemed to be relevant to global governance, no matter how one chooses to define the term. Mine is an effort to explore the analytical clarity of global governance as a concept, primarily by investigating how others - in close and critical interaction with the work of still others-have understood and characterised global governance. Put differently, I am more interested in conducting a second-order conceptual study of first-order conceptualisations of global governance. ${ }^{3}$ Of special interest to me are those first-order conceptualisations which have already wrestled with several empirically oriented texts. ${ }^{4}$

My investigation concentrates on "global governance texts" rather than "global governance scholars". On the one hand, not everything that a particular author writes would be necessarily relevant to global governance or primarily

without quotation marks. I will not provide a definition, but rather will treat the fuzziness of the notion as the very subject of this inquiry.

2 See Jim Whitman, The Limits of Global Governance, (Basingstoke: Palgrave Macmillan, 2005), p. 32; and Matthew J. Hoffmann, "What's global about global governance? A constructivist account", in Alice D. Ba and Matthew J. Hoffmann, Contending Perspectives on Global Governance: Coherence and Contestation, (London: Routledge, 2005), pp. 110-128.

3 For a distinction between first-order and second-order constructs, see Alfred Schütz, Collected Papers I: The Problem of Social Reality [1962], 3rd edn, ed. Maurice Natanson, (Dordrecht: Kluwer, 1982).

4 Throughout the article, I will use the word "text" interchangeably with "study", "piece" and "work", simply to refer to intellectual outputs of differing sizes and formats. I do not feel obliged, in other words, to engage "the text" as a concept in its own right. On this point, see Hans-Georg Gadamer, Truth and Method [1960], ed. Garret Barden and John Cumming, (New York: Seabury Press, 1975) and Roland Barthes, Image, Music, Text [1977], trans. Stephen Heath, (New York: Noonday Press, 1988). 
dedicated to its elaboration. On the other hand, even in those cases, where only a series of works, taken together, are believed to paint a complete picture, it would be possible to identify the contribution made by each single text. Any self-sufficient, single- or co-authored text (article, chapter, book, speech, blog, newspaper column...) which directly engages global governance would be an acceptable subject for analysis. My prioritisation of one piece over another would be influenced by other criteria, as I will clarify further below. While studies which constitute part of dedicated long-term research programmes on global governance may be especially relevant for a focussed investigation, some more occasional stand-alone pieces by one writer or another can also carry enormous weight from a conceptual perspective.

My investigation involves several sub- or side-questions. Even if, realistically, we would not expect to detect any consensus, can we at least identify a limited number of major orientations/clusters for the way globality is being conceptualised? Can we detect conflated but nevertheless analytically separable meanings assigned to globality, i.e. conceptualisations where the ambiguity (perhaps even popularity) of the global actually arises from overlapping/ merged conceptions in need of careful dissection? If our answer to the first and/or second sub-question is affirmative, can we identify actual or potential communication problems (i.e. "talking past each other"), with further implications for theory-building as well as knowledge accumulation?

Having fleshed out my question, let me also provide my answer to that question in advance. Very much in line with what most of us would anticipate, there is no single way globality is understood in the global governance literature, though there seem to be a few relatively well-established clusters of meaning around which the global seems to be conceived and expressed. Still, the globality aspect, which one would reasonably expect to be inherent in any notion of global governance, remains conceptually underdeveloped in the pertinent literature, at least in the sense that proponents of a global governance perspective do not seem to be particularly concerned to clarify, let alone make a case for, their own understanding(s) of globality. ${ }^{5}$

Our approach to globality can be placed on a healthier footing both by way of further conceptual moves within the confines of the global governance approach and by situating it in the wider discussions currently underway in IR about the nature of global/world politics at large. While I concentrate on the

5 The notions of "governance" and "global governance" (the latter taken/perceived as an inseparable whole vis-à-vis other widespread expressions of holistic states of affairs in IR such as "international system", "world order" or "transnational politics") are wrestled with to a larger extent and more rigorously. 
former, I prefer to conclude the article with a few afterthoughts as to the latter. Before I attempt to make my point, I will first say a few words on "conceptual analysis"; specify my research domain; and then go on to analyse the global governance literature with reference to the way it seems to have been handling the global.

\section{1 \\ Conceptual Analysis and the Global}

William Sewell points to anthropologists' widespread "lexical avoidance behaviour" in the 1980s and 1990s vis-à-vis the term "culture", and rightly observes that, despite such behaviour, it will not be possible to control how this term will be used or abused in academic discourse as well as in everyday language. ${ }^{6}$ His punch line is crucial for me: "If, as I believe, ... we cannot do without a concept of culture, I think we should try to shape it into one we can work with. We need to modify, rearticulate, and revivify the concept, retaining and reshaping what is useful and discarding what is not."7 I find Sewell's point about culture highly applicable to global governance. First, people do and will continue to use global governance (like culture) in any number of ways. Even a brief literature review reveals no less than nine separate, though partially overlapping, uses of the global governance "label": international regimes, international society, hegemonic stability, dynamics of globalisation, the pursuit of IMF/World Bank/Un goals, global change/global order, restructuring of the global political economy, world government, and global civil society. ${ }^{8}$ Secondly, I think we should nevertheless try to shape global governance into a concept we can work with.

In engaging the concept, I find much inspiration in Stefano Guzzini's conceptual analysis of "power" for two reasons. First, because it demonstrates that conceptual analysis is not a useless effort, or an aspiration of the past, as it is sometimes portrayed both by empiricists and theorists. ${ }^{9}$ The fact that

6 William H. Sewell, Jr, "The concept(s) of culture", in Victoria Bonnell and Lynn Hunt (eds), Beyond the Cultural Turn: New Directions in the Study of Society and Culture, (Berkeley and Los Angeles: University of California Press, 1999), p. 38.

7 Sewell, Jr (1999), p. 38.

8 This verdict and the nine categories belong to Matthew J. Hoffmann and Alice D. Ba, "Introduction: Coherence and contestation", in Ba and Matthew (2005), p. 1.

9 The "benign neglect" that conceptual analysis has suffered in social sciences in general is noted in Pierre-Marc Daigneault, "Introduction to the symposium 'Conceptual analysis in political science and beyond' ", Social Science Information, 51 (2012), p. 183. 
some important names in IR (including Guzzini himself) still engage in conceptual analysis provides encouragement in its own right. ${ }^{10}$ And also because he is spot on in identifying three separate kinds of conceptual analysis in IR: First, there is the most common understanding of conceptual analysis. Here, Guzzini argues, the main aim (and hope) is to achieve descriptive neutrality for better understanding and communication. ${ }^{11}$ One classic example in political science is Felix Oppenheim's analysis of power. ${ }^{12}$ Guzzini later goes on to criticise this kind of analysis by pointing to the embedded nature of any concept. ${ }^{13}$ Secondly, there is "performative conceptual analysis". Here we see a shift from a concern with, for example, "what is power?" towards "what does power $d o$ ?". ${ }^{14}$ As influenced by the pragmatics branch of linguistics, this type of analysis tries to "understand the meaning of a concept by what its use does."15 Thirdly, conceptual analysis may also refer to the overarching exercise of conceptual history, somewhat subsuming the previous two understandings. ${ }^{16}$ Here the pertinent question becomes how meanings and performative effects

10 See, in particular, David A. Baldwin, "Interdependence and power: A conceptual analysis”, International Organization, 34: 4 (1980), pp. 471-506; Stefano Guzzini, “'Power' in International Relations: Concept formation between conceptual analysis and conceptual history" (Paper prepared for the 43rd Annual IsA Convention, New Orleans, 24-27 March 2002); Stefano Guzzini, "The concept of power: A constructivist analysis", MillenniumJournal of International Studies, 33: 3 (2005), pp. 495-521; and Friedrich Kratochwil, "Politics, law, and the sacred: A conceptual analysis", Journal of International Relations and Development, 16 (2013), pp. 1-24.

11 Guzzini (2005), pp. 500-503.

12 Inis Claude's analyses of balance of power and of collective security as well as Louis Snyder's analysis of nationalism can be cited in this group; see John C. Garnett, Commonsense and the Theory of International Politics, (Albany, NY: SUNY Press, 1984), p. 141.

13 For example, the concept of power that we find in Niklas Luhmann's holistic system theory; see Guzzini (2005), pp. 503-507.

14 One example with respect to the concept of "security" is Jef Huysmans, "Security! What do you mean? From concept to thick signifier”, European Journal of International Relations, 4: 2 (1998), pp. 226-255.

15 Guzzini (2005), p. 508.

16 For example, Friedrich Kratochwil's "On the notion of 'interest' in International Relations" (1982) provides a careful conceptual analysis. He shows not only that interest is a normative (rather than a prescriptive) term but that its meaning shifted dramatically in European international relations in the decades around 1870."; see Jack Donnelly, Realism in International Relations, (Cambridge: Cambridge University Press, 200o), p. 80. A more recent notable example is Jens Bartelson, Visions of World Community, (Cambridge: Cambridge University Press, 2009). 
have been constituted historically and how they have evolved. When subjected to this kind of analysis, the concept of power, for example, is contextualised in two layers. Initially it is placed in a political context, and then in a wider historical context. As Guzzini puts it, the question here becomes: "If it is true that invoking power often has an effect of 'politicising' issues, when, where and how has this become possible?"17

I adopt the first (more traditional) kind of conceptual approach for a number of reasons. First and most important, Guzzini's negative verdict on the first kind of analysis, i.e. that its aim is "descriptive neutrality", is inaccurate and can be adjusted. The aim of the first kind of analysis is, in fact, more simply to find or create a common ground between those who try to communicate. Such common ground need not entail the claim of descriptive neutrality. Secondly, as David Baldwin puts it, while some would be inclined to dismiss this kind of undertaking as mere semantics, we do need to communicate with each other as effectively as possible, and clear(er) concepts indeed seem to help..$^{18}$ For example, analyses which describe, separate and clarify the ways in which particular concepts are being used can reveal any inconsistencies on the part of those who are using these concepts. ${ }^{19}$ The merits of such an approach have also been pointed out specifically in relation to the concept of global governance. ${ }^{20}$ Thirdly, queries which set out to uncover what and how a concept "performs" (e.g. the explicitly social constructivist agenda) are themselves not free from pre-analysis theoretical baggage. Finally, global governance seems to me simply a little too young for a fruitful conceptual analysis of the third kind that Guzzini identifies, i.e. conceptual history. ${ }^{21}$

The fact that global governance is now part and parcel of our everyday vocabulary makes it both difficult and necessary to specify a particular "global governance literature" to which conceptual analysis is to be applied. The wide spectrum of studies clearly relevant to the idea or perspective of global gover-

17 Guzzini (2005), p. 516.

18 Baldwin (1980), p. 472. Jan Aart Scholte makes essentially the same point in relation to globalisation: "Thus every study of globalization should include a careful and critical examination of the term itself. A muddled or misguided core concept compromises our overall comprehension of the phenomenon." See Jan Aart Scholte, Globalization: A Critical Introduction, 2nd edn, (Houndmills: Palgrave Macmillan, 2005), p. 49.

19 Garnett (1984), p. 141.

20 See Klaus Dingwerth and Philipp Pattberg, "Global governance as a perspective on world politics", Global Governance, 12 (2006), pp. 185-203.

21 This, however, is not to deny the possibility that crucial turning points might be identified in the evolution of the discourse over the last two and a half decades. 
nance notwithstanding, ${ }^{22}$ the existence of a "self-labelled global governance literature" has already been usefully noted. ${ }^{23}$ In view of my particular conceptual preoccupation, I prefer to be more specific about what to include in the pertinent global governance scholarship. In one sense, such specification inescapably restricts the domain of global governance literature, because I use three explicit and demanding criteria: centrality, extensive conceptual engagement, and lens of globality as I will clarify below. In another sense, however, I actually widen the scope of the global governance literature, because my inclusion criteria insist neither on academic/scientific work, ${ }^{24}$ nor on identical or conventional output types, ${ }^{25}$ nor, for that matter, on a "friendly" attitude vis-àvis the global governance perspective. ${ }^{26}$ They insist simply on what might be

22 Clearly there are numerous studies, both within and outside the discipline of IR, whose substance is relevant to the idea or perspective of global governance one way or another. It should be equally clear that not everything can be meaningfully considered part of a "global governance literature". One contemporaneous alternative, for example, is the "empire literature"; see Rainer Baumann and Klaus Dingwerth, "Global governance vs empire: Assessing claims on heterarchy and hierarchy in world order", (Paper presented at the Käte Hamburger Kolleg / Centre for Global Cooperation Research Colloquium, Duisburg, 27 November 2012).

23 See Hoffmann and Ba (2005), p. 5. The studies they have in mind have in the meantime secured their place among the standard examples of the literature in question: James $\mathrm{N}$. Rosenau and Ernst-Otto Czempiel, Governance without Government: Order and Change in World Politics, (Cambridge: Cambridge University Press, 1992); Hewson and Sinclair (1999); David Held and Anthony McGrew (eds), Governing Globalization: Power, Authority and Global Governance, (Oxford: Polity Press, 2002); Rorden Wilkinson and Steve Hughes (eds), Global Governance: Critical Perspectives, (London: Routledge, 2002); and Andrew F. Cooper, John English and Ramesh Thakur (eds), Enhancing Global Governance: Towards A New Diplomacy, (Tokyo: United Nations University Press, 2002). Frequent references to a less clearly defined "global governance literature" are readily observable in several other texts as well.

24 Telling apart academic/scientific work from other kinds of work in social disciplines has, in fact, never been as easy as is sometimes assumed, even before the spread of novel forms of dissemination such as Internet blogs. When Stephen Krasner writes a piece for Foreign Affairs (the journal's prestige is generally not questioned, whereas its "academic" nature is) while acting as us State Department's Director of Policy Planning, are his words to be taken seriously for their conceptual, theoretical, and empirical substance, or not?

25 The length or form of a discussion (frequently, if not always, a function of the medium in which a text travels) is irrelevant. What counts is demonstrable conceptual eagerness (and hopefully also depth and quality) which, of course, is bound to be a matter of qualitative interpretation on the part of the "beholder".

26 Some studies assign a central place to global governance, refer to it extensively, and do explore it critically and substantively, but ultimately with a view to discrediting the 
called (for lack of a better expression) a "genuine" conceptual approach to globality in the context of global governance. The criteria are applied sequentially, i.e. the second criterion is applied after the first but before the third. ${ }^{27}$

In the first step, I look for the centrality of the global governance concept for any given empirical analysis or normative judgment. What is important here is to distinguish between those studies which assign, quite explicitly, central importance to global governance as an analytical or normative concept on the one hand, and other studies which seem to tap into the global governance rhetoric, mostly casually, for more descriptive or instrumental purposes. ${ }^{28}$ It is important to see, in other words, that the concept is right at the heart of a text in such a way that, if we attempted to take away the concept from that study, or tried to replace it with alternative concepts, either one or the other (ideally both) of the following would happen: We would have a hard time in keeping the study's gist intact; and the authors would give us a hard time, insisting that their thought can only be expressed by/in (or with persistent reference to) the language of global governance..$^{29}$

Detecting centrality is, for me, a matter of qualitative assessment with a degree of flexibility as to what kinds of clues could be applicable in each case. There are no ready-to-hand formulas for creating indicators, proven to be reli-

"global governance perspective". For example, Latham (1999) and Susanne Soederberg, "Taming corporations or buttressing market-led development? A critical assessment of the Global Compact", Globalizations, 4: 4 (2007), pp. 500-513. Ultimately, this "alternative" global governance literature is more helpful when reflecting on the global than several "pro-global-governance" texts which treat the concept only tangentially.

27 This is simply meant to indicate the practical mental steps taken when considering individual texts. It is not intended as a strict method by which a cumulative research universe is built.

28 Compare, for example, the presidential addresses at the 52nd and 53rd ISA Conventions (by Simmons and Solingen, respectively) with the presidential addresses at the 5oth and 51st ISA Conventions (by Weiss and Lake, respectively). Simmons and Solingen's references to "global governance" are mainly instrumental, whereas Weiss and Lake clearly assign a central importance to the concept. See Thomas G. Weiss, "What happened to the idea of world government", International Studies Quarterly, 53 (2009), pp. 253-271; David A. Lake, "Rightful rules: Authority, order, and the foundations of global governance", International Studies Quarterly, 54 (2010), pp. 587-613; Beth A. Simmons, "International studies in the global information age”, International Studies Quarterly, 55 (2011), pp. 589599; and Etel Solingen, "Of dominoes and firewalls: The domestic, regional, and global politics of international diffusion”, International Studies Quarterly, 56 (2012), pp. 631-644. Global governance, Sinclair notes, "is the new language in which our policy-makers and scholars have learnt to debate the nature of the world's problems since the mid-199os". See Timothy J. Sinclair, Global Governance, (Cambridge: Polity, 2012), p. 9. 
able and valid, which one could automatically take to reveal centrality. To give but one example, prominent mention of the phrase global governance in a study's title or abstract can be woefully misleading. Looking for the following kinds of hints in any given text is generally helpful, though: Is a definition critically offered or adopted? Is there an attempt to justify or critique the language of global governance as an alternative to other languages? How is global governance being positioned vis-à-vis "similar" concepts? Is, for example, the term being frequently used as a substitute for other (indeed competing) terms? ${ }^{30}$ Is the text thought to be an example of global governance thinking by the author and/or by others?

There are countless texts where the term and idea of global governance clearly play no more than a cosmetic role. Armstrong, Farrell and Lambert's short section on "liberal values and global governance", for example, discusses the Liberal vision of world order which, in the authors' view and language, is in search of "substantial levels of global governance provided though transnational policy networks, supranational organisations and international institutions." ${ }^{31}$ This is the only instance where the term global governance appears in the section, apart from the title. Neither this fact, taken alone, nor the fact that only one brief section is devoted to the discussion of global governance within an entire book in the first place might be particularly telling. However, coupled with the section's relaxed references to such other terms as "world order(ing)", "world politics", "world public order", "supranational organisations" and "international law and institutions", one immediately sees that global governance does not really occupy an analytically distinct place in the authors' conception. Regardless of its prominent appearance in the section title, in other words, the use of the term seems descriptive/instrumental rather than conceptual.

There are also more difficult cases in which we find systematic and prudent reference to global governance, but the emphasis of the overall account clearly rests elsewhere. They reveal little of the substance assigned to global governance by their authors, whether or not the authors are in fact deeply committed to the concept. ${ }^{32}$ And then there are also cases where the opposite is

3о For example, "international system", "world order", "global politics" and "transnational regimes" all convey to us a sense of macro-scale state of affairs.

31 David Armstrong, Theo Farrell and Helene Lambert, International Law and International Relations, (Cambridge: Cambridge University Press, 2007), pp. 92-95; quote from p. 93 (emphasis added).

32 Two examples are David Held, "Restructuring global governance: Cosmopolitanism, democracy, and the global order", Millennium, 37: 3 (2009), pp. 535-547; Andrew Hurrell, 
true. These texts seem oblivious to global governance either as a term or as a perspective, but their content is taken by others to exemplify the global governance thinking. For example, Tony Porter's analysis of "global finance" is justifiably part of an important volume on global governance, but it does not assign a central place to the concept in any explicit way, if at all. ${ }^{33}$ Both the former and latter category are clearly related and relevant to global governance literature, and should not be completely set aside or overlooked, but, strictly speaking, they do not constitute part of it.

My second criterion is extensive conceptual engagement. Once the centrality of the concept for/in a text is established, it becomes important whether the text engages global governance conceptually in any substantial and meaningful way. Here I differentiate between those studies which explicitly try to identify and wrestle with the various definitions, classifications and conceptualisations on the one hand, ${ }^{34}$ and other studies which address one or another specific conceptual, theoretical, empirical, or normative dimension of whatever it is that they take to be global governance. ${ }^{35}$ The former set is not necessarily restricted to studies whose primary or only aim is an investigation of the kind I am looking for. They may well have other, more substantive, agendas and emphases. But as long as they demonstrate, somewhere along the way, clear sensitivity to the concept of global governance, and explicitly engage with it, I consider them part of the pertinent global governance literature. The latter set, on the other hand, certainly contains several invaluable studies which carry substantial conceptual weight. However, if their insights for global governance

"One world? Many worlds? The place of regions in the study of international society", International Affairs, 83: 1 (2007), pp. 127-146.

33 Tony Porter, "The late-modern knowledge structure and world politics", in Hewson and Sinclair (1999). A more recent contribution of Porter to another edited volume, in contrast, is clearly related to global governance; see Tony Porter, "Global governance as configurations of state/non-state activity", in Jim Whitman (ed.), Global GovernancePalgrave Advances series, (Houndmills: Palgrave Macmillan, 2009), pp. 87-104.

34 For example, Dirk Messner and Franz Nuscheler, Das Konzept Global Governance: Stand und Perspektiven, (Duisburg: INEF Report, Heft 67, 2003).

35 One example is provided by Gordenker and Weiss who, despite the impression one gets from the title of their article, are concerned, almost to the exclusion of everything else, only with the "NGO phenomenon" in global governance; see Leon Gordenker and Thomas G. Weiss, "Pluralising global governance: Analytic approaches and dimensions", Third World Quarterly, 16: 3 (1995), pp. 357-387. A special issue of the Third World Quarterly, on the other hand, explores exclusively the links between state-society relations and global governance; see Kevin Gray and Craig N. Murphy, "Introduction: rising powers and the future of global governance", Third World Quarterly, 34: 2 (2013), pp. 183-193. 
are only implicit, and especially if their analyses simply "rest" on an unquestioned notion of global governance, which they are happy to take for granted for their main research purposes rather than try to justify, their relevance for my purposes is only secondary. ${ }^{36}$

Several academic as well as non-academic texts which clearly assign a central place to global governance either fail to, or prefer not to, engage the concept. To give an example from outside of academia, several speeches by Pascal Lamy, former wTо Director-General, have persistently referred to global governance. ${ }^{37}$ But the centrality of the concept, i.e. the importance these speeches clearly assign to the concept, is not supplemented by any effort to achieve terminological consistency or by any attempt to specify, clarify and elaborate on global governance as a concept. ${ }^{38}$ One of Lamy's relevant speeches, for example, easily keeps switching between "global", "multilateral" and "international" governance. ${ }^{39}$ And several of his ideas could be expressed equally well, remaining very much loyal to his line of reasoning and to his normative messages, by using other concepts (say, international politics).

In the final step I try to identify that global governance literature which investigates the notion of global governance through, among others, an explicit lens of globality, i.e. with an identifiable emphasis on the global dimension. The main purpose here is to set aside those global governance studies which display almost exclusive preoccupation with either "governance"40 or "global

36 Even if Held and Hurrell's insightful studies (see footnote 32 ) were thought to meet the centrality criterion, for example, they would fail on these grounds in this second step.

37 Examples include his speeches at Bilkent University (Ankara, 15 March 2013) and at China Development Forum (Beijing, 24 March 2013). For full texts, see Pascal Lamy, "DirectorGeneral Pascal Lamy_Speeches and Statements", available at: http://www.wto.org/ english/news_e/sppl_e/sppl_e.htm (accessed: 19 October 2015).

38 A possible exception is his speech at Bocconi University (Milan, 9 November 2009) in which he exemplifies the normative use of global governance.

39 See his lecture at the Institut d'Etudes Politiques de Paris (21 October 2005).

40 "Governance" has been put under scrutiny countless times across a number of disciplines, as a quick look at the "good governance" and "corporate governance" literatures would reveal. Examples of attempts to link these concepts to "global governance" include: Thomas G. Weiss, "Governance, good governance, and global governance: Conceptual and actual challenges", Third World Quarterly, 21: 5 (2000), pp. 795-814; and David A. Detomasi, "International regimes: The case of western corporate governance", International Studies Review, 8: 2 (2006), pp. 225-251. Some notable studies approaching global governance more from the angle of governance (at the expense of globality) include: James N. Rosenau, "Governance in the Twenty-first Century", Global Governance, 1: 1 (1995), pp. 13-43; Lawrence S. Finkelstein, “What is global governance?", Global Governance, 1: 3 (1995), pp. 367-372; Elke Krahmann, "National, regional, and global governance: One phenomenon 
governance taken as a whole". ${ }^{41}$ Interestingly, by this last criterion, several wellknown studies disappear from the sampling universe, including a number of landmark studies for the conceptualisation and theorisation of global governance, in which one would normally expect to have globality addressed in some direct way. ${ }^{42}$

\section{2 Globality Conceptualised}

The relative conceptual neglect that the global suffers can be demonstrated by pointing to the conceptual make-up of significant studies which explicitly problematise, yet still fail to properly address, the global dimension in global governance. Here I will draw only on a few particularly instructive texts. ${ }^{43}$ These studies address globality, in part, by commenting on its empirics. Significantly, though, they also try to probe the global governance literature with reference

or many?", Global Governance, 9: 3 (2003), pp. 323-346; and Thomas Risse, "Global governance and communicative action", Government and Opposition, 39: 2 (2004), pp. 288-313.

41 I am referring here to the understanding (usually implicit) that global governance would only make sense as an integral whole in its own right; as something that could not possibly be grasped by breaking it down into its components, i.e. global governance as/qua global governance. Perhaps two examples of such an approach are Craig N. Murphy, "Global governance: Poorly done and poorly understood", International Affairs, 76: 4 (2000); and Sinclair (2012). The latter work places the term global governance within some accepted macro-theoretical perspectives in IR, and shows, one by one, what the concept of global governance looks like through their lenses. The former, on the other hand, succinctly reinforces Murphy's previous lengthier analysis which places and contextualises global governance within the overall development of industrial capitalism; see Craig N. Murphy, International Organization and Industrial Change: Global Governance since 1850, (New York, NY: Oxford University Press, 1994).

One notable example is: Rosenau and Czempiel (1992). The most extensive treatments related to the global in this volume (as revealed also by its index) can be found on pp. 255-264 (Czempiel writing more on democratisation) and pp. 281-285 (Rosenau focusing on changing global order). But neither section problematises the global conceptually. A more recent example is: Thomas G. Weiss and Ramesh Thakur, Global Governance and the UN: An Unfinished Journey, (Bloomington, In: Indiana University Press, 2010). Here the authors are solely interested in tracing the "five gaps" (i.e. knowledge, normative, policy, institutional, and compliance) in three substantive/empirical issue areas (i.e. security, development, human rights). Globality is not taken as a problem of special interest in its own right.

43 To use the methodological jargon, here I am applying "non-probability" (more specifically: "purposive" or "judgment") sampling. 
to its conceptual approach to globality. And this they do systematically, consciously—not simply casually, instrumentally. In doing so, they offer us useful clues about the question posed here. ${ }^{44}$

Jim Whitman's overall body of work is notable for its engagement with global governance. ${ }^{45}$ His earlier text, in particular, is useful in three different ways. First, because it is one of the few texts in the specified global governance literature, which explicitly promise to tackle the question of globality. One of its chapters is dedicated to this task. ${ }^{46}$ Secondly, because the text canvasses a range of global governance studies; identifies dominant clusters of conceptualisation; and reveals their neglect of the global dimension. Thirdly, and ironically, because the pertinent chapter ultimately fails to deliver what it promises, thereby providing yet another example of the problem at hand: It, too, retreats to a position of questioning the connotations of "global governance" taken as a whole, and loses sight of the more specific globality angle in the process.

It is clear from Whitman's succinct survey that the global governance literature entertains, in the main, four separate notions about its central concept. Accordingly, global governance has signified "enlarged and empowered actor realm", "strengthened multilateralism", "high-level sectoral governance", or "a summative phenomenon". Matthew Hoffmann, for example, exemplifies the state-centric second notion in his constructivist discussion, but partly taps into the first and third notions as well. ${ }^{47}$ It is, however, not clear in Whitman whether any of the four conceptualisations pay particular attention to globality as an integral aspect of its subject matter, and what they end up telling us about the global in global governance. It may well be that they neglect globality at the conceptual level (indeed this is my observation precisely). But equally importantly, Whitman's text, as one of the few serious attempts to explicitly

44 One added advantage of focusing on these few studies is that they also nicely present snapshots of the last two decades of scholarship taken in roughly equal intervals. However, I have not aimed at such artificial periodisation. It is purely coincidental.

45 See Whitman (2005); Jim Whitman, The Fundamentals of Global Governance, (Houndmills: Palgrave Macmillan, 2009); and Jim Whitman (ed.), Global Governance-Palgrave Advances series, (Houndmills: Palgrave Macmillan, 2009).

46 Whitman (2005), ch.3: "Is governance global or just all over the map?"

47 Contrary to the first impression one might get, Hoffmann's notions of "global as multilateral negotiations" and "global as universal participation" both revolve primarily around state participation. The latter notion refers more to the inclusion of every state than anything else. Nevertheless, his account connects with Whitman's first and third notions in that, respectively, the presence and relevance of non-state actors are not completely downplayed, and his portrayal of the governance of climate change dovetails with Whitman's "high-level sectoral governance". See Hoffmann (2005), pp. 118-124. 
adopt the lens of globality, also loses sight of its objective in the end. Why exactly governance is, or may have been, pronounced global in each of the four conceptualisations remains unexplored. The same holds true in the case of Hoffmann's two corresponding notions as well. But at least in Hoffmann we find an attempt to argue that "global participation" in governance (whether multilateral or universal) is in fact a socially constructed recipe, expected and applied even when it is not absolutely necessary.

Closer inspection of the four dominant notions identified by Whitman suggests that at least three of the four cases revolve, conceptually, around an expansion by way of continuous inclusion. "Enlarged and empowered actor realm" is primarily concerned with two kinds of expansion: the growth in the number and types of actors involved in governance, and the growing strength, competence, and authority of these actors. ${ }^{48}$ "Strengthened multilateralism" implies expansion in the sense of constant widening and deepening of the networks as well as effectiveness of one particular type of actor, i.e. the state. ${ }^{49}$ And "summative phenomenon", by its very definition, involves an expansion in that it seeks to paint as holistic a picture as possible, and to incorporate all actors and all activities associated with governance, whenever and wherever they surface..$^{50}$ Only "high-level sectoral governance" seems to steer away from an inherent emphasis on expansion, but even there it is possible to detect expansion and inclusion of a passive kind. "High-level" negotiation, collaboration, or coordination are not necessarily conceptualised as being relatively detached from "lower" levels. In other words, this understanding (which frequently manifests itself in talks about the so-called "global level"), does not necessarily rest on a notion of subsidiarity. ${ }^{51}$ On the contrary, several conceptions of high-level sectoral governance may well envisage top-down patterns of interaction (whether directly vertical or more diagonal) between perceived

48 One obvious question against such a position on globality is, of course, how to deal, conceptually, with the cases of continuous "contraction / exclusion".

49 For an entirely state-centric take on global governance, see Ikenberry, G. John, “A crisis of global governance?", available at: http://americaabroad.tpmcafe.com/ story/2005/9/22/221223/345 (accessed: 16 August 2007).

50 This approach is perhaps best represented in Commission on Global Governance, Our Global Neighbourhood: The Report of the Commission on Global Governance, (Oxford: Oxford University Press, 1995). In the end, Whitman favours this understanding, claiming that the other three "do not inform our understanding of the necessary compass of global governance"; see Whitman (2005), p. 42.

$5^{1}$ But it may be perfectly compatible with Jan Aart Scholte's notion of "transscalarity" which explicitly rejects the principle of subsidiarity. See Jan Aart Scholte, "Reinventing global democracy", European Journal of International Relations, 20: 1 (2014), pp. 3-28. 
layers of sectoral activity.52 Importantly, in all four notions of global governance, taken together, any potential conceptual links between expansion and globality (assuming, for the moment, that it is indeed these links that would render global governance "global" in these different conceptualisations) remain unclear.

In a prominent text of the late 1990s, Robert Latham problematises "what it means to globalize governance". ${ }^{53}$ Interpreting James Rosenau's famous analytic move earlier in the decade, ${ }^{54}$ Latham detects a shift in this regard from "governance that is global" towards the more encompassing notion of "governance in the global", hence suggesting two separate understandings of the global as it appears in the phrase global governance. ${ }^{55}$ His notion of "governance that is global" forces one to think about why and in what sense forms of governance can be taken to be global; "governance in the global", on the other hand, is based on the view that globality is inherently present in contemporary social relations, ${ }^{56}$ anticipating but also stretching Hoffmann's notion of "governance on the globe" (i.e. "management of problems/phenomena that do not nicely fit into the boundaries of existing units") as far to its outer limits as possible. ${ }^{57}$

There is, however, a conceptual difficulty here. The global in Latham's (and indirectly Rosenau's) first notion relates indeed to governance. Globality, if it exists, emerges in this case precisely from the nature and scope of any existing governing arrangements. It comes into being by virtue of those governing arrangements. Inherent in Latham's second notion, however, is a conflated meaning of the global. Neither globality belongs with governance here, nor the discussion of globality belongs with "what it means to globalize governance" as he originally asks. ${ }^{58}$ Here the ontological stance towards the nature of any given issue-area (intimately connected with a presumed set of corresponding

52 Herein lies my own scepticism as to Scholte's (2014) "transscalarity".

53 Latham (1999), p. 25, emphasis original.

54 James N. Rosenau, “Governance, order, and change in world politics", in James N. Rosenau and Ernst-Otto Czempiel, Governance without Government: Order and Change in World Politics, (Cambridge: Cambridge University Press, 1992).

55 Latham (1999), p. 28.

56 The emphases are borrowed from Klaus Dingwerth and Philip Pattberg, "How global and why governance? Blind spots and ambivalences of the global governance concept", International Studies Review, 12 (2010), pp. 703, 705.

57 Hoffmann (2005), pp. 110, 118.

58 This time I have relocated his original emphasis (i.e. from "globalize" to "governance") just to stress my point. 
social relations) actually serves to displace globality: 59 from being an attribute/ adjective of governance towards being an attribute/adjective of the issue area in question and its characteristic social relations. In other words, it is the issue area that is global in this case, not necessarily its governance. The globality of governance is assumed rather than proven or demonstrated. And it is assumed because of a prior assumption about the global nature of an issue area and a set of social relations revolving around and interacting with that issue area.

Writing one decade after Latham, Dingwerth and Pattberg not only tap into his innovative distinction between "governance that is global" and "governance in the global", but also usefully draw attention to the much neglected notions of "non-global governance" and "global non-governance". 60 Somewhat disappointingly, however, their problematisation of the global/non-global in the context of governance/non-governance turns very soon into a discussion of governance rather than of globality in conjunction with governance/nongovernance. By way of three refreshingly atypical examples (i.e. animal rights, abortion, and unemployment) they emphasise, for instance, the difference between formally/densely regulated and informally/less-densely regulated issue areas. This is certainly a plausible way of escaping Whitman's "global governance as a summative phenomenon" which they seem to find analytically meaningless. ${ }^{61}$ But it does not offer an analysis or commentary on the global. If, for example, a conceptual connection is implied here between more formally/densely regulated areas and the global (or the other way around), then this is neither clarified nor necessarily convincing.

In the overall picture emerging from the above representative cases, the meaning of the global in global governance remains as elusive as ever, but one noticeable conceptual fault line suggests itself as a useful tool in rethinking it. It emerges primarily from Latham's analysis, but also cuts through Whitman's as well as Dingwerth and Pattberg's categories, and finds its linguistic expression in the somewhat trivial distinction between global as an adjective of governance and global as an adjective of the pertinent issue area(s).

59 I am using "ontology/ontological" only in its most unrefined sense here to refer to any deeply held conviction that something exists and is real.

6o Dingwerth and Pattberg (2010). Their notion of "non-governance" is not unlike Latham's notion of "dysgovernance"; see Latham (1999), p. 36.

61 Because in the summative notion "that which is not part of global governance remains unclear"; see Dingwerth and Pattberg (2010), p. 705 . 
The conceptual issue in question is closely connected with a permanent problem which is deceptively easy to state, ${ }^{62}$ but enormously hard to tackle in theory as well as in practice: On the one hand, different people may use the same terms/phrases to refer to different things (concrete or abstract). On the other hand, different people may use different terms/phrases to refer to the very same thing. ${ }^{63}$ To keep matters relatively simple, I will exclude several complicating factors. ${ }^{64}$ But for my purposes at least two of the complicating factors need to be kept in mind. First, the very same person can display inconsistent or conflicting uses of terminology. The person's fluctuations may be interacting with the disparate notions s/he has about the same phenomenon, especially if it is an abstract one. Secondly, whether two discussants achieve terminological unity, or apply the same phrase to different reference points, or different phrases to the same reference point (the latter two are difficulties in their own right), the entry point of the third discussant into their discussion is by no means a straightforward matter, because s/he too has a terminology and its corresponding reference points.

I am raising this issue simply to make one basic observation: ${ }^{65}$ While several widespread formulations/phrases furnish the global governance literature with a common language, a common set of expressions, these formulations/phrases have the innate capacity to invoke (in the mind of the first, second or third person) two major different conceptions as to the relationship between globality

62 The conceptual issues I am raising here have connections to what is long considered as the basics of modern linguistics since the early 1930s, drawing on the work of Frege (1892), Ogden and Richards (1923), and Stern (1931). For an overview, see Sergei Nirenburg and Victor Raskin, Ontological Semantics, (Cambridge, MA: The mIT Press, 2004), ch. 3.

63 The existence of different languages is one large-scale manifestation of this phenomenon in the first place.

64 For example, the impact of people's active range of vocabulary on their ability to express themselves. Another example is what Meyer describes as "culturally laden procedures, in which the meaning is not necessarily semantically coded"; see Christian Meyer, "Globalization, robotization, alzheimerization: Three processes of societal hybridization and the future of social interaction", (Paper presented at the Käte Hamburger Kolleg / Centre for Global Cooperation Research Colloquium, Duisburg, 26 February 2013), p. 12.

65 All of this is based, in the first place, on the working assumption that the global governance "discourse" operates primarily in the conceptual space available to, or interacting with, or created by (?) the English language. For example, there are languages where several concepts (say, concepts used for relative spatial orientation such as "in front," "behind," "left" and "right") are absent; see Meyer (2013), p. 12. 
and governance, corresponding, roughly, to Latham's notions, but with further sub-varieties. ${ }^{66}$ Importantly, these two conceptions frequently give rise to, or simply find an expression in, a third and more ambiguous conception as well. The issue begs conceptual awareness and ontological attention.

Consider the phrases "global financial governance" or "global media governance". For some of us, the global in these references may be, conceptually, an attribute of governance. This is, more or less, Latham's "governance that is global", i.e. governance itself is considered to be global here. For others, though, globality may be attached to the very nature of contemporary finance or media. Here the issue area or problem is considered to be global (roughly, Latham's "governance in the global"). For others still, globality may have a more ambiguous yet pervasive reference point, very difficult to pinpoint, and may well lie both in governance as well as finance/media, i.e. a conflated meaning which might be translated into Latham's phraseology as "'governance in the global' that is global". ${ }^{67}$

If we have the first notion, we would not be particularly bothered, at the conceptual level, ${ }^{68}$ with any extensive nature of finance or media in question. ${ }^{69}$

66 This is all the more relevant if we accept Fearon and Laitin's argument about the importance that should be assigned to "ordinary language meanings" for concept development; see James D. Fearon and David D. Laitin, "Ordinary language and external validity: Specifying concepts in the study of ethnicity", (Paper prepared for LiCEP meetings, University of Pennsylvania, 20-22 October 2000); available at: http://web.ceu.hu/ cps/bluebird/eve/statebuilding/fearon-laitin.pdf (accessed: 19 October 2015).

67 Of course, in some cases it is more or less self-evident that global belongs solely with governance, and not with the issue area or problem concerned. The global in "global health governance" or "global food governance", for example, would hardly belong with health and food, unless an explicit claim is being made to suggest otherwise-for example, as in the specialised discipline and practice of "global health"; see Craig R. Janes and Kitty K. Corbett, "Anthropology and global health", Annual Review of Anthropology, 38 (2009), pp. 167-183. The conceptual space that the adjective "global" can penetrate in these formulations is clearly as limited as in cases like "global energy trade" or "global money market". Our conceptual space in the English language would not normally be open to the possibilities of "trade of/in global energy" or "market of/for global money", even though both "global energy" and "global money" are terms that are currently in circulation, and may well give rise to such conceptual space down the line.

68 At the normative level we might be terrified, of course. Or at the analytical level we might try to reconcile this particular notion of ours with any number of other perceived attributes of finance or media.

69 Ronnie Lipschutz exemplifies this notion, when he starts with a problematisation of "rule", and goes on to discuss the shift from global environmental "management" to global environmental "governance". On the other hand, the notion of "global governance of 
Speculatively (to avoid saying "theoretically"), it would be conceivable, for example, to "globally govern" what is perceived to be only local or micro-level finance or media, ${ }^{70}$ either in the sense of a "globe" believed to have become the "governor" (i.e. acquiring the attributes of agency via certain conglomerations of mechanisms, practices, and actors) ${ }^{71}$ or more in the sense that the issue is being governed in most places on earth with a noticeable degree of coordination or perhaps even control.

If we have the second notion, by contrast, we might proceed without being particularly preoccupied, conceptually, with the nature and extent of the governing arrangements in question at all. ${ }^{72}$ Rather, the presence/perception of a "global" issue area or problem would be at the heart of our thinking. ${ }^{73}$ Here it should be observed that we usually assume that a phenomenon whose very existence is organically connected to the most extensive "level" - whether understood in simpler transplanetary or more sophisticated supraterritorial terms $-{ }^{74}$ of course requires or brings along governance arrangements

security" is exemplified by Kavalski. See Ronnie D. Lipschutz, "From local knowledge and practice to global environmental governance", in Hewson and Sinclair (1999), and Emilian Kavalski, "The complexity of global security governance: An analytical overview", Global Society, 22: 4 (2008), pp. 423-443.

To keep matters relatively uncomplicated for illustrative purposes, I am tapping into that mainstream notion of the global which simply moves along the "global-local" spectrum.

71 For example, Chandler argues: "Thus global 'space' has been transformed into global agency and acquires political qualities... What was once just a figurative 'space' now becomes a conscious political and moral collective, a 'community' "; see David Chandler, Hollow Hegemony: Rethinking Global Politics, Power and Resistance, (London: Pluto Press, 2009), pp. 113-114.

72 Regardless of whichever attributes of such arrangements are of interest to us: local, parochial, piecemeal, hierarchical, informal, inter-organisational...

73 For example, Tony Porter insists on using "global finance" throughout his piece. Along the way, he refers multiple times to both "regulation of global finance" and "global financial regulation". Both of these terms seem to refer to the same phenomenon in his mind, deriving their strength from a prior ontological commitment to "global finance". The second term, however, may also connect with a very different conceptualisation of what is going on, i.e. "global regulation" of any financial transaction as in the first notion above, which is centred on governance rather than the issue area/problem; see Tony Porter, "The democratic deficit in the institutional arrangements for regulating global finance", Global Governance, 7: 4 (2001), pp. 427-439.

74 In Scholte's view, there are two major senses in which globality should be understood. The relatively older one refers more simply to "transplanetary relations" (perfectly in line with our everyday perspective informed by territorial geography), whereas the more recent one suggests "supraterritorial relations" with its twin qualities of "transworld simultaneity" and 
structured at that most extensive level. But it would be conceivable in this second case, speculatively at least, to "locally govern" some instantaneous and simultaneous supraterritorial phenomena, either with an emphasis that it is the local elements doing the governing, or more in reference to the view that the acts of governing both take shape and take place in the locale. ${ }^{75}$ Such governance might well be simultaneous and instantaneous in the sense that regulatory input/reaction might develop far more quickly than would be the case traditionally. But it might at the same time be relatively uncoordinated and maybe even spontaneous. Put differently, even when an issue area or a problem is global, its governance need not be; and even when an issue area or a problem is believed to be global, its governance is not necessarily believed to be so.

If we have the third notion (which seems to me to be the most common case), we might be less than clear in our minds, sensing "some sort of globality" somewhere out there, possibly attached to both governance and the issue area in question. We might be conceptually unable or conveniently unwilling to pin it down. But we might be keen on using the phrase "global governance" all the same, so as to vaguely cover a range of possibilities, without having to be clear as to what it is that we are really getting at. ${ }^{76}$ What we have in mind would be either, strictly speaking, global governance of global finance $/$ media, ${ }^{77}$ or more simply, governance of finance/media with some blurred notion of globality vaguely attached to the phenomenon in its entirety. The latter would bring along, as it usually does, all kinds of global governance "talk"s. It would open up

"transworld instantaneity" (where social relations are "delinked" from territorial geography); see Scholte (2005), pp. 6o-61.

75 A point that Hoffmann makes very much in passing is actually highly illuminating this regard: "there are a growing number of 'global' problems like poverty, arms control, terrorism, development, and health that have causes and consequences worldwide that do not require universal participation [in their governance]. Universal participation is not a universal response to global problems". See Hoffmann (2005), p. 121; emphasis original.

76 The popularity of the term "governance" has already been attributed, in part, to its ambiguity; see Oliver Treib, Holger Bähr and Gerda Falkner, Modes of Governance: A Note towards Conceptual Clarification, European Governance Papers No. N-05-02 (2005), available at: http://zsu-schmelz.univie.ac.at/fileadmin/user_upload/inst_politikwiss/Melchior/wso6/ reg/treib-baehr-falkner_-_modes_of_governance.pdf (accessed 20 October 2015), p. 4.

77 "Although finance has become global, its regulation has remained national", observe Mattoo and Subramanian, and go on to suggest that "one option would be to move toward global regulation of finance"; see Aaditya Mattoo and Arvind Subramanian, "From Doha to the next Bretton Woods: A new multilateral trade agenda", Foreign Affairs, 88: 1 (2009), p. 23 . 
a vast but analytically unhelpful conceptual space, whereas such space would normally be more restricted in the previous two conceptions.

In order to stress the discrepancies between the differing notions in question, let me leave governance temporarily aside and point to a somewhat similar set of three formulations, using a different issue area as my example. Think of the potentially deep-lying differences between, for instance, "democracy as a global problem",78 "global democracy as a problem",79 and "global democracy as a global problem". 80 The issue here cannot be easily dismissed simply by calling it "a matter of semantics". When perceived and framed as nothing but a matter of terminological choices or (in)consistency, the problem is relegated into one of casual/instrumental use of words, not to be exaggerated "as if it were" a substantive problem. But it is, in fact, the links between terminological choices and the realm of concepts that make this issue an interesting and relevant one. ${ }^{81}$

From one angle, powerful conceptual differences may be at the roots of different terminological choices; from another angle, terminological choices may have unintended conceptual repercussions in the framing and sharing of analyses. Both of these factors might influence the work of one and the same analyst, resulting in (or simply reflecting) personal conceptual inconsistencies. Both factors may also have, more importantly, a negative bearing on the quality of scholarly exchanges, unless conceptual clarification on this point is explicitly sought and achieved. If it could be shown that all/most of us (as opposed to only some of us) are using these three phrases more or less interchangeably, i.e. meaning and understanding roughly the same framework by all three phrases and having roughly the same broad brush picture in our minds when using and hearing any one of these three phrases, then there would be

$7_{8}$ See, for example, John Keane, "Democracy in the twenty-first century: Global questions", in Terrell Carver and Jens Bartelson (eds), Globality, Democracy and Civil Society, (Abingdon: Routledge, 2011), pp. 112-130.

79 See, for example, Joshua Cohen and Charles F. Sabel, “Global democracy?", NYU Journal of International Law and Politics, 37: 4 (2005), pp. 763-797.

80 If "global democracy" is believed to have already acquired a significant intellectual baggage in its own right, then replace "democracy" with "terrorism", "poverty", "security", "justice", "development" ... just to explore possible connotations in different minds.

81 Consider the so-called "mode of presentation problem", i.e. the problem of "co-referring" expressions which differ in cognitive significance. For example, even when one knows that George Orwell and Eric Blair are the same person, "George Orwell wrote 1984" and "Eric Blair wrote 1984" can connect with quite different notions. See Eric Margolis and Stephen Laurence, "The ontology of concepts—abstract objects or mental representations?", Noûs, 41: 4 (2007), pp. 565, 580-586. 
no problem of the kind I have been talking about. However if some of us carefully distinguish these three phrases from each other either consciously or intuitively, ${ }^{82}$ and others simply equate them in their usage, again consciously or intuitively, ${ }^{83}$ then the conceptual ground on which we exchange views and engage in discussions should be treated as anything but reliable. "Talking past each other" becomes a distinct possibility. What is important is, though, that such possibility is neither simply a matter of "mere semantics", nor does it necessarily indicate "incommensurability". ${ }^{84}$ It more likely indicates the need for conceptual awareness and refinement for the sake of healthier communication and consistency. Such awareness and refinement may, in turn, require closer attention to the ontology of the global.

\section{Connections to Ontology}

Conceptual differences may be indicative of people's incongruent "ontological commitments" at a deeper level. I will, on this point, concentrate purely on some widespread short-hand descriptions involving the global, just to reflect on what is at stake. Scholte's classic book neatly paves the way, for it masterfully illustrates one prevalent mode of thinking in the pertinent literature: 85

The present concise survey merely serves to demonstrate the widespread incidence of transplanetary-including more particularly supraterritorial—circumstances across contemporary social life. Cumulatively, all of this global communication, global travel, global production, global consumption, global money, global finance, global organization, global military, global ecology, global health, global law and global consciousness indicates that contemporary social relations cannot be described without extensive reference to transworld spaces. ${ }^{86}$

82 i.e. each one points to a different vision of reality, a belief in the "existence" of something different.

83 i.e. all three expressions point to the belief in the "existence" of one and the same thing.

84 For an insightful discussion of Feyerabend's original understanding as well as the popularised broader "incommensurability thesis", see Eric Oberheim and Paul Hoyningen-Huene, "Incommensurability, Realism and Meta-Incommensurability", Theoria, 12: 3 (1997), pp. $447-465$.

85 "Manifestations of globality" in Scholte (2005), pp. 67-75.

86 Scholte (2005), pp. 73-74. 
Never mind, for the moment, the different kinds and understandings of globality that may be at play here, a subtle ontological claim is detectable behind several of these phrases in the literature, ${ }^{87}$ whether direct or indirect, explicit or more implicit, as to the existence of a global issue area, of a global problem, i.e. an issue area (a problem) one of whose defining, integral, inescapable characteristics is globality. ${ }^{88}$ Take the global away: the issue area almost disintegrates, the problem almost disappears. It becomes a different animal altogether, begging different kinds of analyses and responses. When he asks what it means "to speak of global governance the way we speak of global culture, global economy, or global security", for example, Latham reinforces the same claim in reference to the latter three categories. ${ }^{89}$ Porter's investigation of certain developments in "global finance" proceeds in the same vein. ${ }^{90}$ Whether understood in the sense of an "integral/indivisible whole" or more in the sense of "similar and simultaneous phenomena observable practically everywhere on earth", it is the issue area /problem that is believed to have a global nature in these instances. Arguably, such phrases as "global economy" or "global security" might be more suitable to capturing the former meaning, while such expressions as "global economic relations" or "global security issues" could capture both the former and the latter equally well. Either way, the global in the mind of the person using these and similar phrases would likely belong with the issue area in question. This, it should be clear by now, is closely related to the second notion discussed in the previous section, and also finds its way into the third notion in different ways.

Perhaps one of the clearest demonstrations of such ontological position with particular reference to global governance comes from Manuel Castells. ${ }^{91}$ "In this lecture", he writes, "the reality of the process of globalization is just an empirical starting point", and goes on to list the main components of that

87 Perfectly expressible in terms of Scholte's own section on ontology; see Scholte (2005), pp. 267-269. See also James N. Rosenau, "Toward an ontology for global governance", in Hewson and Sinclair (1999).

88 The claim may be direct in the sense that an author subscribes to it, or indirect in the sense that the author simply conveys the mindset of several others who subscribe to it. The claim may be explicit in that a text readily declares and consciously elaborates on its belief in the existence of certain things, or more implicit in that the observations, judgments, and analysis, taken together, point to a belief in the existence of some things.

89 Latham (1999), p. 26.

$90 \quad$ Porter (1999), p. 141.

91 Manuel Castells, "Global governance and global politics", Ps: Political Science and Politics, 38: 1 (2005), pp. 9-16. 
(perceived) reality. ${ }^{92}$ At first, one thinks that his use of the word "just" in this context may be signalling his intention to use the empirical world purely instrumentally, i.e. to indicate that "reality" may in fact be different from the way it appears to our senses in interaction with our cognitive faculties and our prior conceptual/theoretical frameworks. Soon it becomes apparent, however, that the emphasis is, rather, on "starting point" in that the lecture's substantive points about global governance are developed against the backdrop of what the lecture indeed holds to be sound and empirically detectable prior "reality". That reality includes (in shortened form, but using the text's exact wording): the existence of a global economy; a global media system; the management of the environment as a planetary issue; the globalization of human rights; and global security as a shared problem. Everything else, i.e. critique, development, reconfiguration of global governance, seems to depend, in this view, on clear acknowledgment of such prior reality.

It is, of course, important to distinguish between the ontological assumptions underlying certain uses of global on the one hand, and any idiosyncratic/ analytic, casual/descriptive, or linguistically awkward uses of global on the other. Gill and Law's "global hegemony", 93 Shaw's "global state", ${ }^{94}$ Habermas' "global domestic politics", 95 or Mittelman's "global bricolage",96 for example, are highly idiosyncratic uses, each serving an innovative and specified analytical purpose. On the other hand, hundreds of such widespread expressions as global agenda, global brand, global outcry, or global leader need not exemplify anything more than casual/descriptive uses of global. For that matter, not all uses of such trickier expressions as global trade, global economy, global security, or global environment are indicative of a subtle ontological claim either. ${ }^{97}$

92 Castells (2005), p. 10; emphases added.

93 Stephen R. Gill and David Law, "Global hegemony and the structural power of capital", International Studies Quarterly, 33: 4 (1989), pp. 475-499.

94 Martin Shaw, Theory of the Global State: Globality as An Unfinished Revolution, (Cambridge: Cambridge University Press, 200o). In fact, in Shaw's case, there is an ontological claim closely attached to globality. But that ontological claim would reveal itself in the expression "global consciousness" rather than in his analytical category of the global state; see Martin Shaw, "Theory of the global state revisited", available at: http://martinshaw .org/2008/06/17/theory-of-the-global-state-revisited/ (accessed: 20 October 2015).

95 See William E. Scheuerman, “Global governance without global government?", Political Theory, 36:1 (2008), pp. 133-151.

96 James H. Mittelman, "Global bricolage: Emerging market powers and polycentric governance”, Third World Quarterly, 34: 1 (2013), pp. 23-37.

97 For example, the tone of his article reveals that Falkner uses "global environment" as nothing more than just a shorthand; see Robert Falkner, "American hegemony and the global environment", International Studies Review, 7: 4 (2005), pp. 585-599. 
In addition, it is always possible to think of scenarios in which someone with limited interest in language or with a provocative agenda would use global in some unusual way, exemplifying a "complete primitive language" in Wittgenstein's sense at best. ${ }^{98}$ What distinguishes an ontological commitment from the rest, as in certain uses of global finance, global media, global security relations, or global ecological interdependence is a given text's overall tone and direction with respect to the concept. Where special, consistent, continuous effort goes into making a "case" as to how, why, and with what implications "global finance" or "global communication" behaves or evolves the way "it" does, or where categorical statements reveal clear conviction on the part of the pertinent author as to its unavoidable/unquestionable existence, there we detect something more than simply analytical or casual use. ${ }^{99}$

My point here is certainly not one about the validity or soundness of the underlying ontology in any analysis. The view that the environment, for example, constitutes a truly inseparable "global" whole above and beyond any artificial boundaries seems to be gaining ground, quite apart from the treatment in the global governance literature. Johan Rockström and his colleagues' highprofile paper published in the prestigious Nature, ${ }^{100}$ seems to have attracted quite a bit of attention for pushing the notion of "planetary boundaries".101 There are, to give another example, dedicated attempts to substantiate finance as a truly global and indivisible phenomenon, as "global finance" proper. ${ }^{102}$ My point, however - and I am now bringing "governance" back in—is simpler and relates purely to the conceptual implications of such ontological commitments for the idea of global governance. A conceptual distinction between "global governance of...", "governance of global..." and "global governance of

98 See Andrew Lugg, Wittgenstein's Investigations 1-133: A Guide and Interpretation, (London: Routledge, 2004), pp. 8-46; and Beth Savickey, Wittgenstein's Art of Investigation, (London: Routledge, 1999), ch. 6.

99 With particular reference to "global finance", see, for example, the discussions in Timothy J. Sinclair, "The infra-structure in global governance: Quasi-regulatory mechanisms and the new global finance", Global Governance, 7 (2001), pp. 441-451, and Porter (2001).

100 Johan Rockström et al., "A safe operating space for humanity", Nature, vol. 461 (24 September 2009), pp. 472-475.

101 Equally pertinent is one main criticism levelled against the paper, namely, that the idea of planetary boundaries fails to distinguish things with truly global effects from those with only a local or regional effect, though. See The Economist, "The global environment: boundary conditions". [16 June 2012], available at: http://www.economist.com/ node/21556897 (accessed: 20 October 2015).

102 An example par excellence is Gordon L. Clark, "Money flows like mercury: The geography of global finance", Geografiska Annaler: Series B, Human Geography, 87: 2 (2005), pp. 99-112. 
global ..." suggests itself as a useful tool in rethinking the global. While we cannot possibly sort out every conceptual problem related to global governance, we can nevertheless make considerable headway through a relatively straightforward mental move, reflecting on global as an adjective of governance versus global as an adjective of the pertinent issue area(s)/problem(s).

5

\section{By Way of Conclusion: Paving the Way for Further Reflection on the Global}

Our approach to globality can be placed on a healthier footing not only by way of further conceptual moves, but by situating it at the same time in wider IR discussions on the nature, indeed ontology, of "global" or "world" politics above and beyond what the many notions of global governance seem to imply. ${ }^{103}$ By way of conclusion, I will briefly touch on three strands of thought in contemporary international political theory (or critical IR theory), which are of particular interest both because they could expand the analytical horizons of the narrower global governance literature and because each of these strands stretches our thinking on globality, quite provocatively, in a completely different direction.

Largely in keeping with various historically sensitive accounts of globalisation, but paying more systematic attention to the evolution of concepts, Jens Bartelson advances an interesting argument. ${ }^{104} \mathrm{He}$ keeps the spotlight on the history of the concept of "the globe", and argues that the global preceded the international. More precisely, a global socio-political space was constructed way before, and in fact enabled, the emergence of the international system of states. ${ }^{105}$ Authority, originally conceived in more global terms, underwent a process of relocation toward the territorial state at some point in history. What seems to be happening now is a reversal of that process. But importantly, the global realm, in this view, has been with us all along, although the analytical priority accorded to the international (for example, in IR theory) has prevented us from grasping the global in any independent terms.

\footnotetext{
103 For my limited purposes in this article, "global politics" and "world politics" can safely be treated as synonyms. However, it should be noted that, for explicit or implicit theoretical reasons, some theorists prefer the former, while others use the latter. For example, see, respectively, Chandler (2009) and R.B.J. Walker, After the Globe, Before the World, (London: Routledge, 2010).

104 Bartelson (2010). See also Bartelson (2009).

105 Bartelson (2010), p. 231.
} 
It is precisely on the point of analytical priority that Rob Walker's intervention becomes significant, and in a particular sense turns Bartelson's argument on its head. ${ }^{106}$ Even if he deliberately resists "developing a predictable and easily summarizable sequence of arguments towards a precise conclusion", 107 the essence of Walker's argument is nevertheless clear from the outset, i.e. we can never reach "world politics" if our starting point happens to be the international in the first place: 108

[A]nyone seeking to reimagine the possibilities of political life under contemporary conditions would be wise to resist ambitions expressed as a move from a politics of the international to a politics of the world, and to pay far greater attention to what goes on at the boundaries, borders and limits of a politics orchestrated within the international that simultaneously imagines the possibility and impossibility of a move across the boundaries, borders, and limits distinguishing itself from some world beyond. ${ }^{109}$

This argument certainly merits further thought, if not uncritical acceptance, when rethinking the global in global governance, especially if one is subscribing to a normative understanding of the concept. The international is typically taken for granted and accommodated, frequently even privileged, in conceptualisations of global governance. The notion that the international may not at all be reconcilable with the global is an unsettling one to say the least.

In stark contrast to both Bartelson and Walker, though sharing several of Walker's meta-theoretical concerns it seems to me, David Chandler makes the case, among others, that the international in a sense actively creates, mediates, reifies the global as an easy way out of multidimensional challenges and

\footnotetext{
106 Walker (2010).

107 Walker (2010), p. 16.

108 At the very least, he does not seem to object to this interpretation of his argument by a number of discussants. See R.B.J. Walker, "World, politics", Contemporary Political Theory, 10: 2 (2011), pp. 303-310.

109 Walker (2010), pp. 2-3; emphases original. His commentary on his critics usefully restates the point: "If one frames one's analysis within the conventions expressed by the AngloAmerican theories of IR, or within the political imaginary expressed in the United Nations Charter, then any attempt to identify a politics that is different from this account of similarity and difference will necessarily run into a very familiar dead end." See Walker (2011), p. 308.
} 
bottlenecks. ${ }^{110}$ In this view, the global suggests itself as a convenient vacuous mental as well as socio-political space in which none of the familiar ties of socio-economic responsibility or democratic accountability is (currently being) articulated or negotiated, except perhaps in a cosmetic sense. And this suits the international very well. "Once the problems of political connections and engagement are reified as external to society", Chandler writes, "the solution appears to be that of embracing, rather than challenging, the shift to the global". ${ }^{111}$ This way:

[governments] no longer govern but campaign or attempt to 'do their bit'. This process enables governments to make a claim of disempowerment at the same time as asserting radical and ambitious agendas - everything from world peace and environmental sustainability to the end of poverty. In this way, the claims made in the international sphere have increased so as to dominate the public agenda, and new international institutions have been established, in areas as diverse as international justice, climate change, development and poverty-reduction, while externally orientated budgets have increased. ${ }^{112}$

I will not further expand on these three ways of thinking on the global here, but I think efforts exemplified by Bartelson, Walker and Chandler provide useful analytical inroads into the nature of globality, and deserve closer attention in conceptual, let alone theoretical, inquiries into global governance. The global dimension inherent in global governance, after all, acquires its content and meaning in (a) broad socio-political setting(s) which we need to keep exploring.

110 For the sake of achieving a common language between the three names in question, I am deliberately overlooking Chandler's argument about the "post-liberal" approach which alters the meanings assigned to the international, to the global, and to the shift from the international toward the global as interpreted within a liberal framework; see David Chandler, "Neither international nor global: Rethinking the problematic subject of security", Journal of Critical Globalisation Studies, 3 (2010), pp. 89-101.

111 David Chandler, "The global ideology: Rethinking the politics of the 'global turn' in IR", International Relations, 23: 4 (2009), p. 542; emphasis added.

112 Chandler (2009b), p. 542. For his fuller treatment of the theme, see Chandler (2009a). 